\title{
Effects Of Illegal Immigration On Security In North Eastern Region Of Kenya
}

Mohamed Hassan Dakane', Dr. Karani Wycliffe Obadiah² And Dr. Manswab Mahsen Abdulrahman ${ }^{3}$

${ }^{1}$ Mount Kenya University, P.O Box 342-00100, Thika, Kenya

${ }^{2}$ School of Social Sciences, Humanities Department, Mount Kenya University

${ }^{3}$ School of Sharia and Islamic Studies, UMMA University

DOI: 10.29322/IJSRP.11.11.2021.p11920

http://dx.doi.org/10.29322/IJSRP.11.11.2021.p11920

\begin{abstract}
Illegal immigrants have been blamed for a number of terrorist attacks, including those on the Westgate, Garissa University, and Lamu County. Considering that North Eastern Region is bordered by Somalia, which has been embroiled in civil war for many years, this study is all the more important. As a result, it focuses on the effects of illegal immigration on security in Kenya's north eastern region. The study's specific goals were to determine the economic effects of illegal immigration on security, to evaluate immigration policy laws on security, and to establish cross-border crimes in Kenya's north eastern region on security. Moral Panic Theory and Sociological Theory were both used in this study. Three sampling techniques were used to arrive at 106 participants who were knowledgeable about the study's topic and had quality information on the effects of illegal immigration in Kenya's north eastern region, which includes Wajir County, Garissa County and Mandera County. Microsoft Excel 2013 was used to edit the completed questionnaires, and the results were tabulated and presented in frequencies and percentages. It was clear violence and conflict; economic opportunities; and human rights abuses in the country of residence have an effect on the safety of the North Eastern. The study concludes that the measures to stop illegal immigration is a difficult one; however, there are presence of multiple immigration policies, and agencies are in place to enforce the protection of North Eastern Region however due to corruption illegal immigration is on the rise in Kenya.
\end{abstract}

Index Terms- Illegal Immigration, Economic effects, Immigration policies, Cross-border crimes, Security

\section{INTRODUCTION}

$\mathrm{T}_{\mathrm{h}}^{\mathrm{t}}$ 1.1 Background to the Study

he focus of this research is on Kenya's North Eastern region's security in light of increased illegal immigration. In this context, immigration refers to the act of moving one's residence to another country. People who are forced to flee their country of origin or exiles who seek refuge in another country fall under this category. These people also include those who have been displaced due to natural disasters such as flooding and prolonged drought (Cannon, 2016, p. 28). Immigration is both a cause and a consequence of globalization, making illegal immigration an increasingly important issue in international relations (Chumba and Were, 2019, p. 42).
According to Lim (2011), illegal immigration has become a major security concern for a number of countries, particularly in Europe, North America, and the Middle East (p. 507-528). As the world's population has grown, so has the fear that unchecked immigration poses a security threat. While 191 million people lived outside their countries of birth in 2005, the number rose to 214 million in 2010. A second way that illegal immigration threatens national security is by impacting the state's economy and social well-being, as noted by researchers Weiner and Myron (2013). (p. 23). As a result of unrestricted immigration, both the country of origin and host nation have experienced significant security threats.

Migrants are fleeing in ever increasing numbers from the Horn of Africa, and from the countries that border it, as well as from within the Horn (Weiner and Myron, 2013, p. 24). In this area, you'll find Ethiopia, Eritrea, Djbouti, Kenya, South Sudan, and the Republic of Sudan, as well as Somalia and the Democratic Republic of the Congo. Conflict, political and ethnic persecusion, poverty, scarcity of resources, degradation of the environment and labor market conditions are just a few of the reasons why many unauthorized immigrants cross into Europe via the southern Mediterranean and North African countries, as well as domestic subsistence strategies in those countries (such as re-reliance). Human trafficking victims become entangled in these currents (Shaw, 2017, p. 76).

The 2010 Kenyan Constitution does not specifically classify the Department of Immigration Services as a security agency. Cybercrime, kidnappings, and the Runda Chinese cyber ring are all migration and security issues stemming from the threat of illegal immigration, as was seen in the Westgate attack, which featured a large number of foreign perpetrators. Kenya's security is jeopardized by illegal immigration, so much of the literature is descriptive (Cannon, 2016, p. 29). Geopolitical forces and poisonous regional ambitions have made Kenya's North Eastern region one of the country's most dynamic and politically turbulent regions over the past several decades. This has made the region extremely volatile. Human traffickers and terrorists have gained entry to the refugee movement because of this. To cite just one example: The Dadaab Refugee Camp orchestrated the DusitD2 Hotel on Nairobi's Riverside Drive (Shaw, 2017, p. 78).

Scholars have testified that illegal immigration has not brought peace to their geographical areas, but none of these scholars have reviewed in Kenya's North Eastern region where the researcher in this study determines to fill the knowledge gap under 
the study topic with various views on global, regional, and local views on security. Criminal activity, religious extremism, money laundering, smuggling, and illegal trade between Kenya and Somalia characterize the North Eastern region (Cannon, 2016, p. 30). The purpose of this study was to determine the effects of illegal immigration on security, examine those effects, and determine the security threats posed by illegal immigrants in Kenya.

\subsection{Statement of the Problem}

Illegal immigration has resulted to many challenges in Kenya from the political, social and economic perspectives, for instance according to the Kenya Police Service's 2015 Annual Crime Report, illegal immigration concerns arise as a result of the world's unprecedented pattern of violent extremism manifesting itself through terrorist attacks on unsuspecting innocent civilian populations, with criminal activities, religious extremism, illegal trade, money laundering, and smuggling occurring in North Eastern.

Due to the paucity and scanty information on illegal immigration in North Eastern Region, it bases this study as important since the region is at the border with Somalia that have been in civil war for many years; hence this research gap needs to be filled through the study on illegal immigrants on security in the Northern Region of Kenya. The study's findings did not only add to the existing body of knowledge, but also served to inform future immigration policies and border control mechanisms.

\section{THEORETICAL FRAMEWORK}

The theories that were discussed in this section include Sociological Theory (Push-Pull) by Hirschi Lee in 1969 and Moral Panic Theory by Stan Cohen in 1973. Therefore, these two theories complement each other in line with research objectives.

\subsubsection{Sociological Theory (Push-Pull)}

The sociological theory was first expounded by Hirschi Lee in 1969. Sociological theory, that later developed into the PushPull Theory, has historically been an interesting way of approaching social problems and how we in turn explain them.

This theory underpins the study objectives for example, if economic advantages are greater in the country of destination than the country of origin, the chances of people moving to such countries increases dramatically and this is automatically influences illegal immigration. Many scholars have described a number of aspects in different ways.

\subsubsection{Moral Panic Theory}

The concept of moral panic was first developed in the United Kingdom in 1973, principally by Stan Cohen, initially for the purpose of analyzing the definition of and social reaction to youth subcultures as a social problem.

This theory is important to the study since the host population there has been increased fear among them as they are not sure of the immigrants' agenda towards their lives, property, lands and general well-being.

\section{RESEARCH METHODLOGY}

\subsection{Research Design}

This publication is licensed under Creative Commons Attribution CC BY.

http://dx.doi.org/10.29322/IJSRP.11.11.2021.p11920
Descriptive research design was adopted in the study; this is justified by the fact that it describes the population and the situation accurately and systematically in phenomenon manner. The present study assumed a descriptive approach for analyzing the relationship between illegal immigration and security in the north-eastern region of Kenya. Illegal immigration and security are independent and dependent variables of the study.

\subsection{Location of the Study}

The study was done in North Eastern Region of Kenya, it comprises of Wajir County, Garissa County and Mandera County. The location is chosen due to the economic recess in the area; porosity of the borders and poor immigration policies are observed in the area. Additionally, it has been witnessed that attacks and criminal activities have taken place in the counties, with security personnel blaming these attacks on illegal immigrants from Somalia.

\subsection{Sampling Technique and Sample Size}

Three sampling techniques were used in the study: simple random sampling, purposive sampling, and snowballing.

The three counties' major towns, including Wajir, Garissa, and Mandera, were randomly selected using a simple randomization technique. Cities were chosen because they were economic centers for the counties and because they were home to County Government offices.

Senior police officers, border patrol agents, and community leaders (Nyumba Kumi Elders) were selected through the use of purposive sampling. Other officers included MCAs, DOCS, OCSs, and Sergeants from the Rural Border Patrol Unit (RBPU). Sub-Chiefs and Chiefs were also selected through the use of purposive sampling.

It was also possible to use the snowball method to collect data from sampling units that were out of reach or not readily available to the researcher. As part of the Chain Method, the researcher went up to the very first participant, who in turn referred him or her to a second person. Due to the sensitivity of the subject, the research did not include any participants from the general public.

Because of this, thirty people from each county were involved in the investigation, including ten senior police officers, ten immigration officers, and even ten community leaders in Kenya's North Eastern Region, and the Interview Guide was conducted with sixteen people, including three MCAs, three Deputy Officer Commanding Stations (DOCSs), three officers commanding stations, and one sergeant from the Rural Border Patrol Unit. As a result, 106 people were included in the study's sample, making the findings applicable to the entire population.

\subsection{Research Instruments}

A structured questionnaire was used to obtain uniform response from the participants for quantitative data while the interview guide was conducted for qualitative aspects of this study. The Interview guide was conducted with sixteen participants that is: 3 MCA's, 3 Deputy Officer Commanding Stations (DOCSs), 3 Officers Commanding Station (OCSs), 1 Sergeant from Rural Border Patrol Unit [RBPU]), 3 Sub-Chiefs and 3 Chiefs, all coming from the three Counties within North Eastern regions of Kenya.

\subsection{Data analysis and Presentation}

Data was cleaned, edited, coded, categorized and analyzed using Ms. Excel. Data collected quantitatively and qualitatively 
was analyzed through descriptive analysis. Data analyzed was presented by use of frequencies, percentages, means and standard deviation in a report format.

\section{RESEARCH FINDINGS}

\subsection{Response Rate}

In table 4.1 gives the response rate, hence the researcher administered a total of 106 that is 90 questionnaires 16 interviews to get the responses of the study population in each County that is: Garissa town, Mandera town and Wajir town. The results were that $79(74.5 \%)$ fully filled and returned the questionnaires and were interviewed; that is questionnaires had a return rate of $63(70 \%)$ while interviews were $16(100 \%)$ return rate. The unreturned rate had a total of $27(30 \%)$ that is only 27 questionnaires were not returned or not fully filled while all the targeted interviewees were interviewed with a rate of $16(100 \%)$. Howell (2013) indicated that a $50 \%$ response rate is appropriate; $60 \%$ of the respondents responded well; and $70 \%$ of the respondents responded very well, so this study's return rate is excellent (p. 23).

\subsection{Economic Effects via Illegal Immigration and Security}

Table 4.6 presents economic impacts and from the data collected majority of the participants strongly agreed that they have observed additional security forces in their area to curb illegal immigration this was shown by 25 (39.9\%), additionally 28 (44.4\%) agreed and $10(15.9 \%)$ disagreed. Based on the findings the participants strongly agreed that job opportunities have been reduced due to cheap labour coming from illegal immigrants this was rated by 29 (46\%), while $20(31.7 \%)$ agreed and $14(22.2 \%)$ disagreed on the statement. Majority of the respondents reported that trade disruption has been seen and this is influenced by illegal immigration and smuggling of goods through porous borders avoiding the customs, this was strongly agreed with 49 (77.8\%), while $14(22.2 \%)$ agreed. This shows that in North Eastern Illegal Immigration influx can also be attributed business opportunities within Kenyan borders and this can bring violence and conflict of interest in such unwarranted and illegal business in the area that negatively affects the business operations in the region.

The participants strongly agreed that job opportunities have been reduced due to cheap labour coming from illegal immigrants, Majority of the respondents reported that trade disruption has been seen and this is influenced by illegal immigration and smuggling of goods through porous borders avoiding the customs. This shows that in North Eastern Illegal Immigration influx can also be attributed business opportunities within Kenyan borders and this can bring violence and conflict of interest in such unwarranted and illegal business in the area that negatively affects the business operations in the region.

\subsection{Immigration Policies and Security}

Figure 4.2 presents the extent to which the immigration policies effect the security in North Eastern Region in Kenya. Based on the data findings the respondents reported that poor implementation of the immigration policies has resulted to rapid influx in illegal immigration that negatively affects the security of the region. This was agreed to a very great extent as shown by 14 $(22.2 \%)$, while the majority agreed to great extent with 49 $(77.8 \%)$. This shows that a country's ability to manage its border effectively is critical to foreigners who visit and leave the country at this entry points. Illegal migrants evade immigration checks or make use of fraudulent documents hence conceal their real identity. The number of illegal immigrants is typically measured by border patrol line watch apprehensions, which is not an ideal metric. This is due to the fact, that it excludes the number of successful illegal immigrants, those attempting to immigrate illegally, and repeat apprehensions for the same individuals.

Majority of the respondents strongly agreed that immigration laws and regulations are not fully implemented due to corruption. Based on the data findings the respondents reported that poor implementation of the immigration policies has resulted to rapid influx in illegal immigration that negatively affects the security of the region. It is clear there is rising insecurity in Kenya and this is due to irregular or regular cross-border immigrants, but with the current poor policies and poor implementation.

\subsection{Cross-Border Crime and Security}

Figure 4.3 illustrates the extent to which cross-border crimes by illegal immigration have influenced the security in North Eastern, Kenya. Based on the data findings the respondents reported that cross border crimes effect security in Northern Kenya to a very great extent as shown by $42(66.7 \%)$, while some agreed to great extent with $21(33.3 \%)$. This implies that illegal migration not only harms the economy and puts a strain on social and economic infrastructure, but it is also linked to other transnational organized crimes such as human smuggling, arms smuggling, and terrorism, to name a few. The primary survival needs of migrants never occur to the smug individuals; as they don't take these into consideration, they end up starving, getting into debt, and putting themselves in dire situations. This shows that if profit-seekers and criminals were to consider them goods for trading, then they would try to keep them under wraps because they're in danger of being suffocated in their trucks, dying in the deserts.

Participants strongly agreed that there no peace due to human and drug trafficking by illegal immigrants. As per the findings on cross border terrorism is observed due to lack of integration between the community and the government was strongly agreed. Xenophobic attacks are observed due to trade disruption by illegal immigrants was strongly agreed. Based on the data findings the respondents reported that cross border crimes effect security in Northern Kenya to a very great extent.

It is clear that without enough policing personnel would mean that a state would not have control on entry of foreigners which would be a recipe for possible insecurity due to entry of illegal and undocumented immigrants.

\section{CONCLUSIONS AND RECOMMENDATIONS}

It was clear violence and conflict; economic opportunities; and human rights abuses in the country of residence have an effect on the safety of the North Eastern. It is obvious that real identities or details of migrants are unknown or cannot be combined with border control schemes that are easily used by terrorists and other international criminals to commit criminal acts underground. Consequently, the threat to national security is posed by illegal immigrants.

The study concludes that the measures to stop illegal immigration is a difficult one; however, there are presence of 
multiple immigration policies, and agencies are in place to enforce the protection of North Eastern Region however due to corruption illegal immigration is on the rise in Kenya. Hence the country's border-management abilities need absolute to be essential for those who come in and go out. Apprehensions by the government at the border don't adequately reflect the number of illegal immigrants.

It can also be concluded that the threats created such as both human and drug trafficking attacks increase along the border, which put the security of the North Eastern Region, Kenya, at risk. It can also be seen that illegal migration impacts the economy, strains social and economic infrastructure, as well as transnational organized crime, to name a few other things. Migrants' primary survival needs are rarely given proper consideration, leading to insecurity within Kenya.

\subsection{Recommendations from the Study}

Based on the outcome of this research report, the following recommendations were made:

i. Some tasks to combat illegal immigration were ineffective despite increased security and police resources. To avoid trade tensions/disruptions, more security forces and jobs are needed. Kenyan border controls must be strengthened to reduce permeability and deter smuggling and trafficking.

ii. In order to combat illegal immigration, the government has passed several regulations and laws. Anti-illegal immigration measures must be improved and targeted better in all immigration agencies, laws, and regulations. To maintain modernised border surveillance integrity, officers must be trained. To begin, educate employees on the Code of Conduct and remove perceived opportunities for corruption.

iii. Developing clear reporting structures from the bottom up can improve agency coordination and cooperation. Human and drug trafficking will decrease, as will xenophobic attacks.

\section{REFERENCES}

[1] [1] Adhikari, P. (2012). The plight of the forgotten ones: Civil war and forced migration. International Studies Quarterly, 56(3), 590-606.

[2] [2] Alvi, M. H. (2016). Munich Personal RePEc Archive. A Manual for Selecting Sampling Techniques in Research, (p. 1-57).

[3] [3] Bonjour, S. (2011). The power and morals of policy makers: Reassessing the control gap debate. International Migration Review, 45(1), 35-122. doi:10.1111/j.1747-7379.2010.00840.

[4] [4] Botha, A. (2019). Radicalisation in Kenya - Recruitment to al-Shabaab and the Mombasa Republican Council, Institute of Security Studies, Pretoria. (p.76).

[5] [5] Bryman, A. (2008). Social Research Methods, Fourth edition, Oxford University Press, New York, (p. 29).

[6] [6] Cannon, B. J. (2016). "Terrorists, Geopolitics and Kenya's Proposed Border Wall with Somalia." Journal of Terrorism Research", ( p. 28-37).

[7] [7] Chumba, C., Okoth, G. \& Were, E. (2019). Effectiveness of Border Surveillance Strategies in the Management of Transnational Terrorism in Kenya and Somalia. International Journal of Political Science 2, no. 2 (2016): $42-66$

[8] [8] Cohen, S. (1973). Folk devils and moral panics. London: Paladin, (p. 76).
[9] [9] Czaika, M. \& Hobolth, M. (2016). Do restrictive asylum and visa policies increase irregular migration into Europe? European Union Politics, 17(3), 5665. doi: $10.1177 / 1465116516633299$.

[10] [10] De-Haas, H. (2015). The determinants of international migration: Conceptualising policy, origin and destination effects (2nd Ed., Vols. 32/2011, pp. 61-62). Oxford: International Migration Institute (IMI).

[11] [11] Department of Immigration (2016). Examination report on the systems, policies, procedures and practises of the ministry of immigration and registration of persons. Pp 50-56. Available at http://erepository.uonbi.ac.ke/bitstream/handle/11295/153936/Maobe_Enfor cement $\% 20$ of $\% 20$ Kenya $\% 20$ Immigration\%20Laws\%20-

$\% 20 \% 20 \mathrm{a} \% 20$ case $\% 20$ of $\% 20$ the $\% 20$ Directorate $\% 20$ of $\% 20$ Immigration $\% 2$ 0Services.pdf?sequence=1\&isAllowed=y. Accessed 14th September 2021.

[12] [12] Government of Kenya (GOK). (2011). The Kenya Citizenship and Immigration Act (KCIA), No. 12 of 2011(Revised Edition 2018). Nairobi: The National Council for Law Reporting (with the Authority of the Attorney General).

[13] [13] Government of Kenya (GOK). (2012). The Kenya Citizenship and Immigration Regulations (KCIR), 2012. Nairobi: Government Printers.

[14] [14] Howell, W. (2013). Fear of persecution: Forced migration, 1952-1995. Journal of Conflict Resolution, (Vol. 5, p. 23).

[15] [15] International Organization for Migration, (2013). Glossary on Migration. International Migration Law Series No. 25, p. 13.

[16] [16] Kenya National Bureau of Statistics [KNBS], (2019). Census Survey Report (CSR) 2009-2019, p. 72. KNBS.

[17] [17] Kenya National Commission on Human Rights, (2019). An Identity Crisis? A Study on the Issuance of National Identity Cards. Nairobi, KNCHR publications. 13(1-2), p.57-72

[18] [18] Lim, K. (2011). South Korea as an 'ordinary' country: a comparative inquiry into the prospects for 'permanent' immigration to Korea. Journal of Ethnic and Migration Studies 38, no. 3: pp. 507- 528.

[19] [19] Migration Data Portal (2021). Migration Data in eastern Africa Available at; https://www.migrationdataportal.org/regional-dataoverview/eastern-africa. Accessed 14th September 2021.

[20] [20] Myron, M. (2013). Climate instability, urbanisation and international migration. The Journal of Development Studies, (Vol. 5, p.23-752). doi:10.1080/00220388.2015.1121240.

[21] [21] Odhiambo, E. O. S., Kassilly, L.T., Maito, K., Onkware, U. \& Oboka W. (2012) "Kenya's Constitution and child trafficking as a security threat." Journal of Defense Resources Management 3, no. 2: (p. 75-88).

[22] [22] Otieno A. (2020). Speech During police and Citizens Forum, Office of the Inspector General, 26th May 2020.

[23] [23] Shaw, W. (2017). "Migration in Africa: a review of economic literature on international migration in 10 countries." World Bank, Memo: (p.76-78).

[24] [24] Triandafyllidou, A., \& Maroukis, T. (2012). Migrant smuggling: Irregular migration from Asia and Africa to Europe. London: Palgrave Macmillan. (p 52).

[25] [25] Vogt, W. Paul, Gardner, D., C. \& Haeffele, L., M. (2012). When to Use What Research Design. New York: Guilford, (p. 26).

[26] [26] Weiner, K \& Marion, T. (2013). Climate instability, urbanisation and international migration. The Journal of Development Studies, (Vol. 5, p.23).

[27] [27] Wissink, M., Düvell, F., \& van Eerdewijk, A. (2013). Importance of boarder surveillance: A transit migration hub in Turkey. Journal of Ethnic and Migration Studies, 39(7), 3-1105. doi:10.1080/1369183X.2013.778026.

\section{AUTHORS}

First Author - Mohamed Hassan Dakane, Mount Kenya University, P.O Box 342-00100, Thika, Kenya, Email: mohamed.dakane@gmail.com

Second Author - Dr. Karani Wycliffe Obadiah, School of Social Sciences, Humanities Department, Mount Kenya University Email: karaniobeds@gmail.com

Third Author - Dr. Manswab Mahsen Abdulrahman, School of Sharia and Islamic Studies, UMMA University

Email: manswab83@yahoo.com 
Correspondence Author - Mohamed Hassan Dakane

Email: mohamed.dakane@gmail.com

Mount Kenya University, P.O Box 342-00100, Thika, Kenya

\section{TABLES AND FIGURES}

Table 4.1 Response Rate

\begin{tabular}{l|l|l|l|l|l}
\hline Response Rate & Frequency & \multicolumn{2}{l|}{ Percentage } \\
\hline & Questionnai & Interview & Total & Questionnaires & Interview \\
Returned Rate & res & & & & \\
Un-returned Rate & 63 & 16 & 79 & $70 \%$ & $100 \%$ \\
Total & 27 & 0 & 27 & $30 \%$ & \\
\hline
\end{tabular}

Source: (Field Research Data, 2021)

Table 4.6: Economic Effects

Source: (Field Research data, 2021)

\begin{tabular}{llllll}
\hline Economic Impacts & $\begin{array}{l}\text { Strongly } \\
\text { Agree }\end{array}$ & Agree & Neutral & Disagree & $\begin{array}{l}\text { Strongly } \\
\text { Disagree }\end{array}$ \\
\cline { 2 - 4 } & & &
\end{tabular}

\begin{tabular}{|c|c|c|c|c|c|c|c|c|c|c|}
\hline & 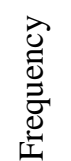 & $\begin{array}{l}\overrightarrow{0} \\
\stackrel{0}{0} \\
0\end{array}$ & 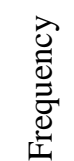 & $\begin{array}{l}\overrightarrow{0} \\
\stackrel{0}{0} \\
0\end{array}$ & 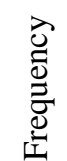 & 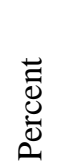 & 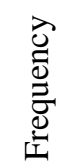 & 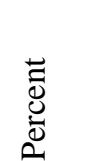 & 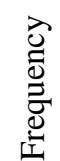 & 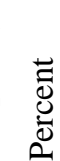 \\
\hline $\begin{array}{l}\text { Additional security forces to } \\
\text { curb illegal immigration. }\end{array}$ & 25 & $39.9 \%$ & 28 & $44.4 \%$ & 0 & 0 & 10 & $15.9 \%$ & 0 & 0 \\
\hline $\begin{array}{l}\text { Job opportunities reduced due } \\
\text { to cheap labor from illegal } \\
\text { immigrants. }\end{array}$ & 29 & $46 \%$ & 20 & $31.7 \%$ & 0 & 0 & 14 & $22.2 \%$ & 0 & 0 \\
\hline $\begin{array}{l}\text { Trade disruption via illegal } \\
\text { immigration and smuggling of } \\
\text { goods. }\end{array}$ & 49 & $77.8 \%$ & 14 & $22.2 \%$ & 0 & 0 & 0 & 0 & 0 & 0 \\
\hline
\end{tabular}

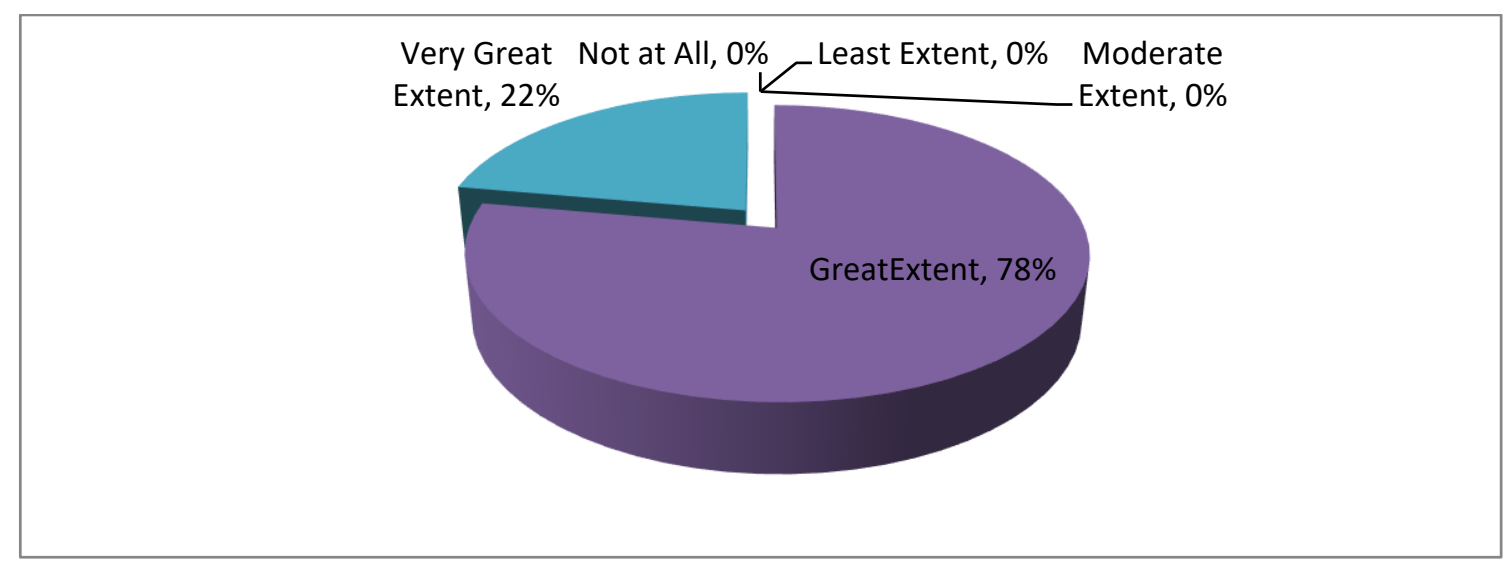

Source: (Research Data. 2021)

Figure 4.2: effects of Immigration Policies on the Security 


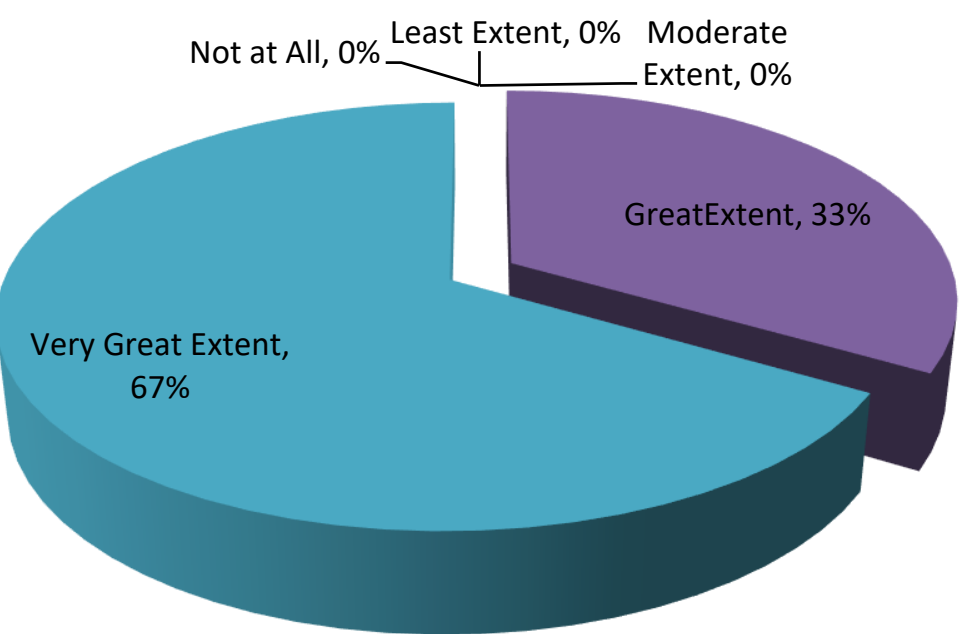

Figure 4.3: Measures to Curb Illegal Immigration and Security Source: (Field Research Data, 2021) 